\title{
The Transformative Power of Breath: Music, Alternative Therapy, and Medieval Practices of Contemplation
}

\author{
Denis Renevey
}

Unlike Eastern meditative practices in yoga, Buddhist, or Hindu traditions, the Western medieval mystical tradition does not provide general technical advice about the practice of contemplation. Furthermore, it is silent about the role played by breathing in the practice of contemplation and does not address the question of the transformative power of volitional breathing. This essay aims to shed light on volitional breathing activities as performed within the context of the contemplative practices of medieval English mystics. It assesses the way in which volitional breathing, combined with socio-religious practices, contributes significantly to the alteration of consciousness, which triggers mystical experiences in the form of ecstasies or visions, or any other movement of the consciousness that transcends everyday reality.

\section{Renevey $(\bowtie)$}

English Department, University of Lausanne, Quartier UNIL-Chamberonne Bâtiment Anthropole, Lausanne, Switzerland

(C) The Author(s) 2021

D. Fuller et al. (eds.), The Life of Breath in Literature, Culture and Medicine, Palgrave Studies in Literature, Science and Medicine, https://doi.org/10.1007/978-3-030-74443-4_6 
In view of the absence of evidence in medieval texts, I rely on practice and theory derived from manuals for brass players, but also applicable to wind instruments in general. ${ }^{1}$ Pranayama, the art of breath control practised in Eastern meditative traditions, can also help us speculate about the importance of breathing for medieval mystics. Luce Irigaray has shown how Western philosophical tradition has abandoned breath in its epistemological considerations. ${ }^{2}$ Lenart Škof and Petri Berndtson also deplore the loss of thinking and breathing as 'a chiasmic relation in which the thinker and the experience of breathing somehow constantly intertwine in an essential manner, perpetually inspiring each other' ${ }^{3}$ It is therefore not surprising that traditional Indian spiritual practices, with their insistence on the power of breath, should attract interest from Western philosophers; nor that they should also be used by 'new age' movements, packaged for audiences interested in quick access to 'the spiritual'. One such 'new age' practice is Holotropic Breathwork, of special interest for its claim that hyperventilation offers one of the most effective means of modifying consciousness beyond the confines of the rational, a claim of particular relevance in investigating the possible function of breathing patterns in the practice of medieval mystics.

The medieval material used for this investigation is limited to the writings of two medieval English mystics, Richard Rolle of Hampole, a fourteenth-century Yorkshire hermit, and the author of the mystical treatise The Cloud of Unknowing, possibly a Carthusian monk active in the late fourteenth century, who remains anonymous to this day. Both writers share a common interest in the practice of contemplation based on the repetition of short prayers, and it is mainly as related to this specific spiritual practice that I offer hypotheses on the role of the transformative power of breath.

Producing a sound from a wind instrument depends on the player's production of wind. Arnold Jacobs (1915-1998), long-standing tuba player of the Chicago Symphony Orchestra, and perhaps one of the best brass teachers ever, offers a simple but significant statement about breath in his teaching: 'Breathing to play an instrument is clearly different from breathing to live'. ${ }^{4}$ Jacobs' teaching focused particularly on breath. He developed simple but powerful breath exercises that led to the improvement of sound production by his students. Breathing to play requires a 
move from natural to volitional breathing that implies knowledge about one's own respiratory functions and abilities, as well as practice in the control of airflow, away from the instrument or, in the case of singing, without sound production. ${ }^{5}$

Breathing can be divided into three phases: inhalation, exhalation, followed by a brief pause. When we inhale, our respiratory system searches for oxygen; the exhalation phase deals with the expulsion of carbon dioxide. Volitional breathing for the practice of a wind instrument, a category to which brass instruments like the tuba, the French horn, the trombone, and the trumpet belong, relies on one of the three forms of breathing characterized according to physiological parameters. Diaphragmatic breathing, or deep breathing, makes use of the lower part of the lungs and full use of the diaphragm muscle. Jacobs describes the diaphragm in the following way: 'The diaphragm is a muscular partition between the thoracic and the abdominal cavities. Its location, in the front, is at the base of the sternum (breastbone) and in the back on the spine and at the base of the rib cage'. ${ }^{6}$ Diaphragmatic breathing is central to the practice of brass instruments. It allows for the production of pressurised air which is required for an airflow that will produce notes: the higher the notes the more pressurised the air has to be. Proper use of the diaphragm keeps other parts of the body (neck, throat, face muscles, lips) free from unproductive pressure. The second form of breathing is intercostal breathing, which takes place just above the diaphragm, at the level of the rib cage. Intercostal breathing produces a movement pushing the thoracic cage outward. The third, clavicular breathing, is located at the apex of the lungs, with the air placed at the high extremity of the lungs, and therefore pushing the thoracic cage upwards. The combination of these three forms of breathing in yoga practice is called 'full breathing'. It can be practised volitionally and has therapeutic benefits, in increasing energetic potential, stimulating creativity and sensitivity. It has also the ability to help individuals reach a sustained level of relaxation and balance. ${ }^{7}$

Diaphragmatic breathing, also called deep breathing, is at the heart of brass playing. Michel Ricquier's Traité méthodique de pédagogie instrumentale contains a series of thirteen breathing exercises, all emphasising deep breathing. ${ }^{8}$ Central to the teaching of both Ricquier and Jacobs is their emphasis on the need to use breath efficiently to create wind to play a wind instrument. ${ }^{9}$ Deep breathing can easily be experienced if one experiments with an exercise suggested by Ricquier, which consists in first 
adopting an upright sitting posture, with hands joined as if praying, with elbows touching one another. Once the elbows are pressed against the abdomen, the practitioner should spread his/her legs and lean downwards and breathe. This position will automatically impose a deep breathing mode. This deep breathing, according to yogic philosophy, has positive physiological and emotional effects. It also makes possible the compression of the air required for playing a wind instrument. Deep breathing can easily be practised in that position, but is much more difficult to maintain in an upright position. The exercises that follow in Ricquier's treatise aim to help the practitioner maintain deep breathing when moving from this position to the standing position of the solo performer. The combined information offered from a medico-physiological perspective (Jacobs) and a perspective influenced by the yoga practice of pranayama (Ricquier) shows the extent to which breath participates actively in the life of both body and mind. As a way of maintaining deep breathing in all circumstances, Ricquier invites the practitioner to imagine the breathing phenomenon as taking place at the level of the substernal hole, near the diaphragm muscle, and to forget the passageways of the lips, mouth, trachea, and upper part of the lungs. In order for the compression of air to take place at this level, without the uninvited participation of these other physical organs, one should imagine the air going down when both inhaling and exhaling. This vertical downward movement, working as a piston, depends on the diaphragm as its foundation. It is called the air column, and is used for efficient brass instrument playing. ${ }^{10}$ Although Ricquier, like Jacobs, is initially interested in providing food for thought and practice to brass players, he also realizes that the potential benefits of proper breathing go beyond the practice of wind instruments. Indeed, Ricquier links this practice to pranayama, the dynamics of breath in the yoga tradition and the desire to improve well-being. ${ }^{11}$ There is indubitably a close connection between the practice of volitional deep breathing as part of brass instrument practice and meditation centred on breathing. For instance, in addition to the breathing exercises mentioned above that are common practice among professional brass players as part of their daily warm-ups, playing long notes for tone, pitch, stamina, and sound improvement depends completely on airflow control. Normal exhalation is usually less than four seconds, while sustained sound production may last as long as twenty to thirty seconds. This therefore depends on the controlled release of air, closely resembling the yoga practice 
mentioned above, and the practice of repetition of short-word prayers indicated by some medieval English mystics. ${ }^{12}$

While most Western philosophical and theological writing does not engage directly with the practicalities or transformative potential of breathing in contemplative practice, various schools of yoga rely on pranayama as part of their teaching. ${ }^{13}$ One of the foundational texts on pranayama is the Yoga Sutra of Patanjali (ca. $400 \mathrm{BCE}-400 \mathrm{CE}$ ), which offers a culturally constructed view of breath, from organic and animal life at one end of the spectrum, to the spiritual dimension at the other. The point of pranayama and other Eastern schools of philosophy based on breathing is that a move along that continuum, from the organic to the spiritual, can be reached by the acquisition of breathing techniques. The move from involuntary to volitional breathing allows for a change of quality in the breathing process, a change achieved through practice similar to the regular breathing exercises undertaken by brass players in their daily warm-up routines, which they keep practising as part of their musical performances. But as Cleo McNelly Kearns notes, practical techniques in matters of spirituality in the Western tradition are perceived as antithetical to infused grace, and therefore not regarded as necessary for contemplative practice. So, the absence of technical instruction concerning contemplative activity in the writing of Richard Rolle or the Cloud-author is culturally motivated. And yet the following aspects are paramount to efficient prayer. First, conscious breathing should be intimately linked to speaking, and therefore to praying, with much significance given to silence. ${ }^{14}$ Second, controlled breathing (therefore controlled speaking and praying-and playing, as we have seen above) should be practised, with the expectation that it triggers spiritual transformation. Also, however ineffable and disembodied some aspects of contemplation may be, the reliance on breath in contemplative practice situates it strongly in the body. ${ }^{15}$

Luce Irigaray's investigation of Eastern spiritual traditions has led her to contend that transformation of our elemental breath into something more subtle and controlled helps heart, thought, and speech. Breathing is therefore at the heart of her respiratory philosophy, developed from Indian spiritual practices. The Forgetting of Air in Martin Heidegger (1983) represents a turning point in Irigaray's thought, leading her to propose a new age, the 'Age of the Breath'. Her deep knowledge of Western philosophy and her experiential approach to yogic breath work are shown in the conscious and thoughtful breathing which is at the heart 
of her reflections in Between East and West. Irigaray here applies breathing techniques from yoga and pranayama to Western forms of spiritual practices, such as prayer. She offers convincing evidence that 'breath itself and the kinds of religious discipline related to it are situated in the body'. ${ }^{16}$

The examples from both brass instrument playing and pranayama show, therefore, how a move from organic to volitional breathing can have profound transformative power in relation to the physical and spiritual make-up of practitioners. Jacobs and Ricquier both show the extent to which regular breathing exercises transform the ability to produce efficient wind for the production of sound, while the latter explores further the physical and spiritual benefits induced by conscious and wider-ranging breathing patterns that include deep breathing and full breathing. The transformation of consciousness induced by such practice is attested by the changes in the quality of sound production as well as contact with the inner self. Although the latter may not be the primary objective of musical practitioners, it is an aim comparable to those of yoga schools: Irigaray's reference to 'spirited' breath, which involves complete inhalation and complete exhalation, brings about results similar to the exercise of full breath discussed by Ricquier. ${ }^{17}$

If producing efficient wind leads to a state of well-being that helps an individual get in touch with the inner self, the production of sound on brass may also have unwanted effects in relation to maintaining a certain clarity of mind for proper performance. In normal situations, the concentration of oxygen and carbon dioxide in the blood that is the result of breathing varies constantly. The oxygen that we breathe is brought to the tissues by the blood, and carbon dioxide is the waste product that we exhale. ${ }^{18}$ In some circumstances, the ratio between oxygen and carbon dioxide can be unfavourable, thus contributing to an alkaline shift in the blood's $\mathrm{pH}$. This may result in hyperventilation, the effects of which Jacobs describes in the following manner:

When you hyperventilate a bit, you actually alter the $\mathrm{pH}$ (potential hydrogen) of the body. The alkaline/acid relationships are affected, and a person is apt to feel a little bit peculiar with very moderate hyperventilation. Usually it will start out as dizziness. How will I say it—a little leaving of the ground-you begin to float a little bit. The symptoms of hyperventilation are due to a lack of carbon dioxide and its effect on the brain. The carbon dioxide is washed out of the blood by the heavy breathing 
(increased ventilation) of the respiratory system. Keeping the air flow into the tuba at the maximum, makes the person feel dizzy. ${ }^{19}$

Jacobs's scientific experiments with researchers at the Pulmonary Functions laboratory at the University of Chicago led to several major discoveries with regard to brass players' abilities to breathe without the symptoms of hyperventilation. The scientists were also aware of its effects on the brain. In the context of musical performance, hyperventilation is to be avoided at all costs as performers find themselves in situations that require control of all their faculties for a good quality performance. In the case of Jacobs, hyperventilation was avoided by inhaling back carbon dioxide through his tuba. However unwanted the experience during musical performance, what Jacobs calls 'a little leaving of the ground-you begin to float a little bit', can clearly be said to be an alteration of consciousness generated by increased ventilation. Volitional breathing and breathing performed during strenuous physical exercises can lead to hyperventilation as well, and thus to significant changes of consciousness. $^{20}$

Though the contemporary therapeutic practice of Holotropic Breathwork has a different status from the more tried and tested practices of a traditional Eastern religion and the breathing techniques of brass teachers, its focus on hyperventilation as a trigger for transformation of consciousness offers a link with the description of one of its effects by Jacobs, that is, 'a little leaving of the ground'. While Jacobs offers suggestions as to how to avoid hyperventilation and its unwanted effects, Holotropic Breathwork offers hyperventilation as its main tool for altered consciousness. This focus on accelerated breath and the positive outlook on hyperventilation as contributing to the alteration of consciousness may be of interest in assessing the role played by breath in medieval mystical experiences. Holotropic Breathwork considers that the brain contributes to mediating consciousness, but does not actually generate it. It stipulates that we have no evidence that consciousness is produced in the brain and by the brain. Rather, like a television set, the brain absorbs and conveys material that is generated outside the brain, depending on the connections that it has made with external sources. ${ }^{21}$ Holotropic Breathwork allows for the brain to be connected with immanent and transcendental sources that feed spiritual experiences. As the main propagators of the technique, Stanislav and Christina Grof, write: 
In holotropic states, our consciousness can reach far beyond the boundaries of the body/ego and obtain accurate information about various aspects of the material world that we have not obtained in this lifetime through the mediation of our sensory organs. We have already mentioned reliving of birth, of prenatal memories, and of conception. In transpersonal experiences our consciousness can identify with other people, with members of various species of the animal kingdom from primates to unicellular organisms, with plant life, and even with inorganic materials and processes. We can also transcend linear time and experience vivid ancestral, racial, karmic and phylogenetic sequences, and episodes from the collective unconscious. $^{22}$

Holotropic Breathwork situates itself in a long tradition of psychospiritual systems that have sought to understand human nature and have 'viewed breath as a crucial link between the material world, the human body, the psyche and the spirit'. ${ }^{23}$

The practice of Holotropic Breathwork consists of faster breathing, evocative music, and releasing body work. ${ }^{24}$ It emphasizes the ability of volitional breathing to influence consciousness. Hyperventilation and prolonged withholding of breath are two of the best means to generate such alteration. Holotropic Breathwork, its practitioners claim, acknowledges the many different states of consciousness that each individual may experience, allowing the brain to connect with personal, perinatal, and psycho-spiritual dimensions that cannot be accessed in a normal state of consciousness. The holotropic state is reached via accelerated breath, as is made clear by the guidance given to a breather in the context of a workshop:

Now that your body is more relaxed, open, bringing attention to your breath ... feeling the normal, everyday rhythm of your breath ... and as you continue to be aware of your breath, beginning to increase the rhythm of your breathing ... so your breath becomes faster than usual ... allowing the breath to travel all the way to your fingertips, all the way to your toes, as the breath fills the entire body ... the breath is quite a lot deeper and faster than usual ... Now increasing the rhythm of the breath even more ... so that it becomes faster than usual, and deeper ... and deeper and faster ...

At this point, if you have a source of inspiration in your life, you may try to connect with it asking for guidance ...

So by now, the breath is quite a lot deeper and faster than usual ... As the music begins, allowing the music to support your breathing ... finding 
your own rhythm ... Opening yourself to the breath, to the music, and whatever experience that presents itself. ${ }^{25}$

Holotropic Breathwork, which consists mainly of accelerated and deep breathing, leads, its practitioners suggest, to a wide spectrum of experiences, some of them mystical. This 'new age' practice demonstrates the continuing desire for altered states of consciousness. The results it claims to achieve by inducing hyperventilation suggest the possibility that the effects of unsolicited hyperventilation may have been causal factors in the transformation of consciousness in medieval contemplative practice.

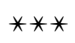

Although Western medieval mystics are silent about techniques of contemplation in general and breathing in particular, it is justifiable to assume that breathing was part of their spiritual routines and to assess whether volitional breathing led them to move to the spiritual end of the breathing spectrum. Also, even if their volitional breathing did not tend towards accelerated breathing leading to hyperventilation, it is worth considering whether some of their experiences may have been generated by unsolicited hyperventilation. The aim of the second part of this essay is to consider these possibilities in the context of the practice of short one-word prayers as advocated by Richard Rolle and the anonymous Cloud-author. The early fourteenth-century Yorkshire mystic Richard Rolle is one of the staunchest proponents of ceaseless prayer in the form of devotion and prayer to the Name of Jesus. The prayer was well-known in both Western and Eastern Christian traditions. ${ }^{26}$ When reduced to its simplest form, it consisted in both traditions in the repetition of the name, in Middle English 'Ihesu'. Examples of the use of the prayer to the Name of Jesus abound in Rolle's corpus. ${ }^{27}$ But more importantly, statements about the presence of the name 'Ihesu' in Rolle's mind show the degree to which it became an essential component in the shaping of his state of consciousness. For instance, Rolle writes the following about the Name in his Melos amoris:

Dum vigilo, non vaco a voce vitali: si legerem, si scriberem, si ambulem, si agerem, continuo canorem concentu cupitum; si comedam, si bibam, non cadit a corde nomen notandum solum in quo salvari me sencio securum. Non obliviscar Illius qui animum assumpsit ut ardens anhelem Ipsi adesse. 
Sine Iesu non iubilo qui genitum me gessit a gemitu et gelu ut germiner ingenuus ierarchie. Et cum sedeo inter suspirantes ad seculare solacium, dum non garriunt ut clangentes michi in secreto quod non sciunt, acsi essem in requiem restauratus, resultat organum angelicum et sonat, sed subtilissime, celica symphonia.

[When I watch, this powerful voice does not leave me. Whether I read or write, whether I walk or work, the harmonious song I love continues. Whether I eat or drink, from my heart the only Name which is worthwhile mentioning stays with me; I am confident about salvation. I cannot forget the one who has taken possession of my soul that I long to be in his presence.

Without Jesus I do not jubilate. From birth he protected me from the weeping and from the cold, so that I could grow, introduced as I had been among the angelic line. Even when I am in the middle of those who long for the pleasures of this century, as long as they do not break my ears shouting secrets they ignore, the angelic music resounds within me as if rest was given back to me, and the celestial symphony resounds very delicately. $]^{28}$

In Rolle's Oleum effusum, the Name serves to fight off the demon, disguised in the shape of a woman. ${ }^{29}$ In Incendium amoris, Rolle states on several occasions how much his unceasing devotion to the Name contributes to his spiritual state. ${ }^{30}$ References to devotion to the Name of Jesus in these treatises indicate that it was used by Rolle in different ways and for different purposes. Using his preferred sitting posture, which he mentions on several occasions, Rolle would have repeatedly pronounced the word 'Ihesu' during controlled and sustained exhalation phases, thus forcing a pattern of breathing that he would have closely scrutinized. The breathing rhythm imposed by such practice would necessarily be diaphragmatic breathing, leading to an initial state of well-being that would bring about a change in state of consciousness. The intoning of this short one-word prayer in one's own familiar language invites a focus on the sound of the word itself, on the quality of silence between each intonation, and on the quality of breath. ${ }^{31}$

Rolle is also unique among medieval English mystics in recommending the sitting posture as the preferred one for his contemplative activity. Two significant moments that are part of his conversion begin with reference to his being seated in a particular chapel: 
Sedebam quippe in quadam capella, et dum suauitate oracionis uel meditacionis multum delectarer, subito sentiui in me ardorem insolitum et iocundum...

Dum enim in eadem capella sederem, et in nocte ante cenam psalmos prout potui decantarem, quasi tinnitum psallencium uel pocius canencium supra me ascultaui... Puto tamen neminem illud accepturum, nisi specialiter nomen Ihesum diligat, et eciam in tantum honoret ut ab eius memoria numquam, excepto sompno, recedere permittat.

[I was sitting in a certain chapel, delighting in the sweetness of prayer or meditation, when suddenly I felt within myself an unusually pleasant heat...

While I was sitting in that same chapel, and repeating as best I could the night-psalms before I went into supper, I heard, above my head it seemed, the joyful ring of psalmody, or perhaps I should say, the singing ... All the same I fancy that no one will receive them (celestial joys) unless he has a special love for the Name of Jesus, and so honours it that he never lets it out of his mind, except in sleep. $]^{32}$

In the following chapter Rolle describes his solitary state as a sitting posture ('sedens in solitudine') and, more significantly, he projects his heavenly stay as being seated in Paradise (' in paradise positus'). ${ }^{33}$ The sitting posture becomes a hallmark of Rolle's spirituality, one that he even includes in the lyric that concludes Ego dormio, one of his three epistles, written for the attention of a nun of Yedingham: 'I sytt and syng of luf langyng pat in my breste es bredde/ Jhesu, Jhesu, Jhesu when war I to pe ledde?"34

Ricquier recommends the sitting posture in order to experience deep breathing. In view of the significance of breathing to the practice of short prayers, it is not impossible that Rolle's preference for that posture was linked to the ease it allowed in finding a good breathing pattern for the practice of the unceasing prayer devoted to the name 'Jhesu'. Interestingly, the practice of the Jesus prayer in orthodox spirituality, which can be reduced to the simple utterance of the word 'Jesus', also offers the sitting posture as the best for its practice. But unlike Rolle, who seems to have kept to a traditional sitting posture, with the torso upright, the hesychast method practised by mystics of the Eastern Orthodox Church on Mount Athos proposes a position very similar to that of the diaphragmatic breathing postulated by Ricquier: 
St Gregory of Sinai advises sitting on a low stool, about nine inches high; the head and shoulders should be bowed, and the eyes fixed on the place of the heart. He recognizes that this will prove exceedingly uncomfortable after a time. Some writers recommend yet more exacting posture, with the head held between the knees, following the example of Elijah on Mount Carmel. 35

Modern-day practitioners of the Jesus prayer provide very useful information about coordination with heartbeat and breath in order to integrate it with oneself:

Prayer is not meant to be a sporadic occurrence. It must be assured of continuity. It must be given room to live, as surely as there must be room in a person's life for his heart and his breathing. As important as my breathing and heartbeats is my steady prayer to Jesus. To practise this constant praying by mechanically co-ordinating it with the beat of the heart or the work of the lungs is just one way of really providing prayer with this room of its own. ${ }^{36}$

The unceasing quality of the Jesus prayer discussed here matches some of the comments made by Rolle about his own practice, as well as reflecting the number of lyrics or lyrical moments in his prose treatises that integrate the name 'Ihesu' with his devotional outbursts.

An example of the accommodation of the name 'Jhesu' occurs within the lyric that concludes Ego dormio, at a moment when Rolle provides tools to reach the highest level in the contemplative life, according to three degrees of love. This lyric is offered as part of the third and highest degree of love, called 'contemplatife lyfe'. The lines beginning with 'Jhesu' appear to function according to the same breathing paradigm described above for intoning the name 'Ihesu'. Each verse, preceded by a quick inhalation, is uttered during the course of one exhalation, thus creating a breathing pattern that is regular and under the control of the will. Although no technical instruction is provided for this iteration, or for the reading of the whole epistle, the rhythmical pattern invites breathing that very much follows the deep and volitional breathing pattern discussed earlier: 37

Jhesu, my dere and my drewry [sweetheart], delyte ert pou to syng. Jhesu, my myrth and melody, when will pow com, my keyng? Jhesu, my hele [cure], and my hony, my whart [joy] and my comfortyng, Jhesu, I covayte for to dy when it es pi payng [pleasure]. ${ }^{38}$ 
Unlike Irigaray, I would not want to disentangle meaning from intoning. They work superbly together here to facilitate a change of consciousness that will bring the reader to the highest and final degree of love. However, insistence on the role of breathing as part of these highly performative exercises gives them a strong physical grounding. This spiritual medicine has been tested by Rolle himself who mentions elsewhere that he practised devotion to the Name ceaselessly, day and night, with the effect that he was brought to a state of consciousness which made it possible for him to hear heavenly song continuously. Reading is therapeutic in part because it forces volitional breathing, which often leads one to develop deep breathing, which is known to have therapeutic properties. ${ }^{39}$

Rolle is not alone in proposing short one-word prayers. The Cloudauthor also shows interest in the practice of short prayers. His most well-known text, The Cloud of Unknowing, stands out in medieval English writing as the most representative of the apophatic tradition. This tradition provides instructions on how to experience contact with the divine by suggesting a self-emptying, a noughting of the mind's images and concepts in order to let the divine pour itself in. This approach asserts that no image, object, or concept derived from the created world can successfully convey any aspect of the divine. It resists any form of comparison of the created world with divinity. This text and its companion piece, The Book of Privy Counselling, are unique in Middle English in using the apophatic tradition for contemplative practice.

Considering that annihilation and avoidance of analogies made to the divine and the created world are at the heart of the apophatic approach, it is not surprising that the Cloud-author proposes a set of short prayers for the practice of contemplation. Chapters thirty-seven to forty-one provide very useful information about the practice of short prayers. The Cloudauthor asserts with great conviction his belief in their efficacy. He writes:

A man or a womman, affraied wip any sodeyn chaunce of firr, or of mans deep, or what elles pat it be, sodenly in pe heizt of his speryt he is dreuyn upon hast \& upon nede for to crie or for to prey after help. 3e, how? Sekirly not in many woordes, ne zit in o woorde of two silabes. \& whi is pat? For hym pinkep to longe tariing, for to declare pe nede \& pe werk of his spirit. \& perfore he brestip up [bursts out] hidously wip a grete spirit, \& cryep bot a litil worde of o silable, as is pis worde FIIR or pis worde OUTE. ${ }^{40}$ 
This passage gives prominence to the need, in situations of emergency, of voicing as quickly as possible the will of the speaker. In this particular case, the passage emphasizes the power of breath in voicing the words 'fiir' or 'oute'. As the Cloud-author writes, 'he brestip up hidously wip a grete spirit'. The idea of bursting out takes into account the physiology of urgent speech that forces one to take a quick deep breath in order to utter powerfully the words of warning that need to be heard by those who are in danger. I also contend that the Cloud-author employs 'sperit' with multiple meanings, such as 'vital breath', 'emotion', or simply 'breath or air'. ${ }^{41}$ His words insist on the physical and physiological dimension of uttering short words with conviction and power, and it is this very physiological aspect that he transfers to the practice of praying with onesyllable words. Indeed, like 'fiir' or 'oute' in the above example, they express powerful urgency and desire for transformation, unmediated by unnecessary affect and metaphorical language. Before suggesting specific words, he offers detailed information about the role of prayer, as a 'deuoute entent directe vnto God, for getyng of goodes \& remowyng of yuelles'. 42 'Synne' and 'God' are two of the words proposed for prayer by the author, although one may also be stirred by God to use certain words, such as 'love'. Although the semantic range of each word plays an important function in the efficacy of each prayer, I would like to emphasize the physiological process, more particularly the breathing patterns, required for its performance. The Cloud-author is quite specific about the way in which such prayers should be performed. Indeed, they are part of what he, like Rolle, calls ceaseless praying. The Cloud-author is very precise when he writes that 'it schuld neuer sees tyl pe tyme were pat it had fully getyn pat pat it longid after' ${ }^{43}$ Mention is made of the possibility of creating formulaic prayers based on the repetition of a combination of one-syllable words. For instance, the following sequence is mentioned: 'Synne, synne, synne; oute, oute, oute'. The Cloud-author specifies that the prayer can be voiced or practised inwardly. ${ }^{44}$ In both cases, silent or vocal performance would need to work in synchrony with a controlled breathing pattern that, if practised with the sense of urgency described in the first passage, would rely on deep breathing.

While the Cloud-author does not insist as much as Rolle on the posture that should be adopted while contemplating, The Book of Privy Counselling nevertheless associates the intoning of a short word with the love of sitting alone: 
Fewe ben pi wordes, bot ful of frute \& of fiir. A schorte worde of pi moup contenep a woreld ful of wisdam, 3it semep it bot foly to hem pat wonen [dwell] in here wittis. Pi silence is softe, pi speche ful speedful [profitable], pi preier is preue [personal], pi pride ful pure [guiltless], pi maners ben meek, pi mirpe ful mylde, pi list [craft, desire] is likyng to pleye wip a childe. Pou louest to be only $\&$ sit by pi-self; ,... ${ }^{45}$

The Cloud-author advocates restraint in many areas of the contemplative life: few words, short words, silence, private prayer, nothing more ambitious than to play with a child, and, importantly, to love to sit in solitude. Affective devotional restraint is also one of the characteristics of the apophatic tradition to which these texts belong. In this respect, The Cloud of Unknowing and The Book of Privy Counselling contrast significantly with the affective spirituality of Richard Rolle. But in other respects, the desire for solitude, the sitting posture, and prayers based on a few short words point to a world of silence in which breath finds its organic place and is shaped at will for the contemplative to reach his or her inner being in communion with the divine.

Breathing techniques associated with brass instrument playing, yoga, and Holotropic Breathwork offer interesting clues concerning the role played by breath in these different practices. In all these cases, breath is both essential and strongly embodied, showing that alteration of consciousness is physiologically triggered. Since information about breathing in the context of medieval contemplative practice is lacking, this discussion of modern breathing practices in complementary contexts can help us understand better the transformative power that breath had in the practice of one-syllable word prayers. The fact that Rolle and the Cloud-author do not offer practical instructions for their one-word prayers should not detract from investigations of the power breath has as part of contemplative practice. Breathing to live spiritually implies volitional breathing that fulfils therapeutic functions and leads to the discovery of realms of experience that go beyond the rational horizon of expectations. Combined with divine grace, volitional breathing contributed to some of the most inspiring lived experiences of medieval English mystics. 


\section{Notes}

1. As a brass player (trumpet and French horn), I practise these exercises on a regular basis. Although I have never taken part in Holotropic Breathwork sessions, I have practised meditation based on a one-syllable word.

2. See Luce Irigaray, Between East and West: From Singularity to Community, trans. by Stephen Pluhácek (New York: Columbia University Press, 2002); also Lenart Škof and Emily A. Holmes, Breathing with Luce Irigaray, Bloomsbury Studies in Continental Philosophy (London: Bloomsbury, 2013).

3. See Lenart Škof and Petri Berndtson, 'Introduction', in Atmospheres of Breathing, ed. by Lenart Škof and Petri Berndtson (Albany: SUNY, 2018), ix-xxvii (xi).

4. Briand Frederiksen, Arnold Jacobs: Song and Wind, ed. by John Taylor (Gurnee, IL: WindSong Press, 2012), Kindle, loc. 2943.

5. For further information on the exercises advocated by Jacobs, see 'Arnold Jacobs Almost Live: Breathing Exercises', YouTube, <https://www.you tube.com/watch?v=KrNmbaRq10Y> [accessed March 3, 2019].

6. Frederiksen, Arnold Jacobs, loc. 3028.

7. See Michel Ricquier, Traité méthodique de pédagogie instrumentale (StJean d'Arvey: T.M.P.I., 1976), 99-106.

8. See Ricquier, Traité méthodique, 15-46.

9. I am paraphrasing Ricquier, Traité méthodique, 15.

10. Ricquier, Traité méthodique, 37.

11. Ricquier, Traité méthodique, 25. Interestingly, Ricquier's second book moves somewhat away from his initial concern with brass instrument playing. His L'Utilisation de vos ressources intérieures: Dans votre activité instrumentale, artistique, sportive, etc. (Paris: Billaudot, 1984) deals with the pursuit of fulfilment of one's own full being.

12. Frederiksen, Arnold Jacobs, loc. 3055-61.

13. Cleo McNelly Kearns, 'Irigaray's Between East and West: Breath, Pranayama, and the Phenomenology of Prayer', in The Phenomenology of Prayer, ed. by Bruce Ellis Benson and Norman Wirzba (New York: Fordham University Press, 2005), 103-18. For various explorations of a 'respiratory philosophy', see Škof and Berndtson (eds), Atmospheres of Breathing.

14. On the process of silence as part of contemplative practice, see Maggie Ross, Silence: A User's Guide, Vol. 1: Process (London: Darton, Longman and Todd, 2014).

15. McNelly Kearns, 'Irigaray's Between East and West', 104-05.

16. McNelly Kearns, 'Irigaray's Between East and West', 105.

17. McNelly Kearns, 'Irigaray's Between East and West', 116.

18. Frederiksen, Arnold Jacobs, loc. 3110. 
19. Frederiksen, Arnold Jacobs, loc. 3117. I have experienced this kind of dizziness on a few occasions when playing the trumpet.

20. During summer hiking camps in the Swiss Alps friends occasionally suffered from hyperventilation when going up a mountain top. The way to stop the associated dizziness was to breathe into a plastic bag, so as to take in carbon dioxide in order to balance the ratio with oxygen. This is a very similar method to that described by Jacobs with his tuba. This technique is also described by Grof as a means of suppressing spontaneous hyperventilation; see Stanislav Grof and Christina Grof, Holotropic Breathwork: A New Approach to Self-Exploration and Therapy (Albany, NY: State University of New York Press, Excelsior Editions, 2010), Kindle, loc. 923-30.

21. Grof and Grof, Holotropic Breathwork, loc. 812-23.

22. Grof and Grof, Holotropic Breathwork, loc. 823-28.

23. Grof and Grof, Holotropic Breathwork, loc. 885.

24. Grof and Grof, Holotropic Breathwork, loc. 869.

25. Grof and Grof, Holotropic Breathwork, loc. 1600.

26. For a summary of Western tradition, see Denis Renevey, 'The Emergence of Devotion to the Name of Jesus in the West', in Aspects of Knowledge: Preserving and Reinventing Traditions of Learning in the Middle Ages, ed. by Marilina Cesario and Hugh Magennis (Manchester: Manchester University Press, 2018), 142-62.

27. See, for instance, the Incendium amoris, Emendatio vitae, The Form of Living, and Ego dormio, as examples of the inclusion of the devotion to the Name within Rolle's mystical system. For a brief description of Rolle's spiritual and textual legacy, see Tamás Karáth, Richard Rolle: The Fifteenth-Century Translations, Medieval Church Studies 40 (Turnhout: Brepols, 2018), 13-33.

28. Richard Rolle, Le Chant d'amour, 2 vols, ed. by E. J. F. Arnould, intro. by François Vandenbroucke, Sources Chrétiennes 168-9 (Paris: Editions du Cerf, 1971), vol. 1, 134.

29. For a Middle English version of this text, see Richard Rolle: Uncollected Prose and Verse, ed. by Ralph Hanna, EETS 329 (Oxford: Oxford University Press, 2007), 9-11.

30. For instance, chapters $36,38,40,41$, and 42 show the extent to which Richard Rolle has integrated the prayer to the Name of Jesus: see Richard Rolle, Incendium amoris, ed. by Margeret Deanesly (Manchester: Manchester University Press, 1915), 248, 250, 267, 272-73, and 278.

31. See McNelly Kearns, 'Irigaray's Between East and West', 109; Irigaray discusses the intoning of prayers in non-familiar languages, thus displacing discursive meaning and drawing attention to sound, silence, and breath. 
32. Richard Rolle, Incendium amoris, 189-90; Richard Rolle, The Fire of Love, 2nd edn, trans. by Clifton Wolters (London: Penguin, 1988), 93-94.

33. See Richard Rolle, Incendium amoris, 193.

34. See English Writings of Richard Rolle, Hermit of Hampole, ed. by Hope Emily Allen (Gloucester: Alan Sutton, 1988), 71.

35. Bishop Kallistos of Diokleia, The Power of the Name: The Jesus Prayer in Orthodox Spirituality, rev. edn (Oxford: SLG Press, 1986), 25.

36. See Per-Olof Sjögren, The Jesus Prayer, rev. edn, trans. by Sydney Linton (London: Triangle, 1996), 44.

37. English Writings, ed. by Allen, 69 .

38. English Writings, ed. by Allen, 71 .

39. These exercises participate in what Daniel McCann considers to be therapeutic reading: see Daniel McCann, Soul-Health: Therapeutic Reading in Later Medieval England, Religion and Culture in the Middle Ages (Cardiff: University of Wales Press, 2018); see also Daniel McCann, 'Blood and Chocolate: Affective Layering in Swete Ihesu, Now wil I Synge', in Middle English Lyrics: New Readings of Short Poems, ed. by Julia Boffey and Christiania Whitehead (Cambridge: Brewer, 2018), 45-56.

40. The Cloud of Unknowing and The Book of Privy Counselling, ed. by Phyllis Hodgson, EETS 218 (Oxford: Oxford University Press, 1944), 74.

41. See 'sperit', Middle English Dictionary, <https://quod.lib.umich.edu/ $\mathrm{m} /$ middle-english-dictionary/dictionary/MED42245> [accessed July 9, 2019].

42. The Cloud, 77.

43. The Cloud, 78.

44. The Cloud, 78.

45. The Cloud, 166-67.

\section{Selected Bibliography}

Arnold Jacobs. Almost Live: Breathing Exercises. https://www.youtube.com/ watch?v=KrNmbaRql0Y. Accessed March 3, 2019.

Frederiksen, Brian. 2012. Arnold Jacobs: Song and Wind. Ed. John Taylor. Gurnee, IL: WindSong Press.

Grof, Stanislas, and Christina Grof. 2010. Holotropic Breathwork: A New Approach to Self-Exploration and Therapy. Albany, NY: State University of New York Press, Excelsior Editions.

Kallistos, Bishop of Diokleia. 1986. The Power of the Name: The Jesus Prayer in Orthodox Spirituality. Rev. edn. Oxford: SLG Press.

McCann, Daniel. 2018. Soul-Health: Therapeutic Reading in Later Medieval England. Religion and Culture in the Middle Ages. Cardiff: University of Wales Press. 
McNelly Kearns, Cleo. 2005. Irigaray's Between East and West: Breath, Pranayama, and the Phenomenology of Prayer. In The Phenomenology of Prayer, ed. Bruce Benson and Norman Wirzba, 103-18. New York: Fordham University Press.

Renevey, Denis. 2018. The Emergence of Devotion to the Name of Jesus in the West. In Aspects of Knowledge: Preserving and Reinventing Traditions of Learning in the Middle Ages, ed. Marilina Cesario and Hugh Magennis, 14262. Manchester: Manchester University Press.

Ricquier, Michel. 1976. Traité méthodique de pédagogie instrumentale. St-Jean d'Arvey: T.M.P.I.

Ross, Maggie. 2014. Silence: A User's Guide. Vol. 1: Process. London: Darton, Longman and Todd.

Sjögren, Per-Olof. 1996. The Jesus Prayer. Rev. edn., trans. Sydney Linton. London: Triangle.

Open Access This chapter is licensed under the terms of the Creative Commons Attribution 4.0 International License (http://creativecommons.org/licenses/ by $/ 4.0 /)$, which permits use, sharing, adaptation, distribution and reproduction in any medium or format, as long as you give appropriate credit to the original author(s) and the source, provide a link to the Creative Commons license and indicate if changes were made.

The images or other third party material in this chapter are included in the chapter's Creative Commons license, unless indicated otherwise in a credit line to the material. If material is not included in the chapter's Creative Commons license and your intended use is not permitted by statutory regulation or exceeds the permitted use, you will need to obtain permission directly from the copyright holder.

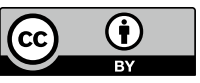

